Public Policy under Thatcher 


\title{
Public Policy under Thatcher
}

\author{
Edited by \\ Stephen P. Savage \\ and \\ Lynton Robins
}

Macmillan Education 
ISBN 978-0-333-53660-5

DOI 10.1007/978-1-349-20855-5

ISBN 978-1-349-20855-5 (eBook)

Selection and editorial matter (C) Stephen P. Savage and Lynton Robins 1990 Individual chapters (in order) (C) Rob Atkinson: Mike Dunn and Sandy Smith:

Rob Atkinson and Carol Lupton; David Farnham; John Bradbeer; Stephen P. Savage; Ian Kendall and Graham Moon: Rob Atkinson and Paul Durden; Macolm McVicar: Neil Evans; Francis McGlone: Sylvia Horton; Carol Lupton and Dave Russell; Kelvyn Jones, Frances Millard and Liz Twigg: Frank Lyons: Fergus Carr 1990 Softcover reprint of the hardcover 1st edition 1990 978-0-333-53659-9

All rights reserved. For information, write:

Scholarly and Reference Division.

St Martin`s Press, Inc., 175 Fifth Avenue.

New York. N.Y. 100100

First published in the United States of America in 1990

ISBN 978-0-312-05014-6

Library of Congress Cataloging-in-Publication Data

Public Policy under Thatcher / edited by Stephen P. Savage and Lynton Robins.

p. $\mathrm{cm}$.

Includes bibliographical references and index.

ISBN 978-0-312-05014-6

1. Great Britain-Politics and government-1979-2. Great

Britain-Economic policy-1945- 3. Great Britain-Social

policy-1979- I. Savage, Stephen P. II. Robins, L. J. (Lynton J.)

JN231.P83 1990

$941.085^{\prime} 8 \mathrm{dc} 20$

90-38032

CIP 


\section{Contents}

Acknowledgements $\quad \mathrm{x}$

Notes on the Contributors

Glossary of Acronyms and Political Terms xv

Introduction 1

Post-war Politics and Policy Prior to 1979

Politics and Policy Since 1979

1 Government During the Thatcher Years Rob Atkinson 8

Introduction $\quad 8$

Government at the Centre 9

Government at the Local Level 16

Non-traditional Forms of Government 18

Extra-national Forms of Government 19

Conclusion $\quad 22$

2 Economic Policy and Privatisation Mike Dunn
and Sandy Smith

The Keynesian Approach $\quad 23$

Growing Disillusionment 25

The Monetarist Challenge 28

The Thatcher Revolution $\quad 29$

Changing Emphasis 31

Supply-side Economics $\quad 32$

Privatisation $\quad 34$

The Phases of Privatisation 1979-90 37

The Impact on Industrial Performance 39

The Beneficiaries 41

The Thatcher Economic Experiment 41

3 Towards an Enterprise Culture? Industrial and Training

Policy Under the Conservatives Rob Atkinson

and Carol Lupton 45

Industrial Policy - Pre-1979 46

Industrial Policy Since $1979 \quad 47$

Regional Policy Pre-1979 50

Regional Policy Since 1979

Training and Enterprise Policy - Pre-1979 52 
The 1979-87 Thatcher Administrations 53

The Conservative Administration Since 1987

Conclusion $\quad 57$

4 Trade Union Policy 1979-89: Restriction or Reform?

David Farnham $\quad 60$

The Conservative Party and the Unions 61

Weakening Collectivism and the Role of the Unions 62

Strengthening the 'Right to Manage' 64

Regulating and Reducing Union Power and Influence in the

Labour Market 66

Depoliticising Trade Unions and Industrial Relations 69

Conclusion $\quad 71$

5 Environmental Policy John Bradbeer $\quad 75$

Introduction $\quad 75$

The Environment as a Popular and Political Issue: its Rise.

Fall and Resurrection

Environmental Policy Since 1979

Discussion of Policies Adopted 85

6 A War on Crime? Law and Order Policies in the 1980s Stephen P. Savage 89

Introduction $\quad 89$

Law and Order Policy - 1979-85 90

Law and Order Policy Since 1985

Criminal Justice Acts 1987 and 1988

Crime Control in the Community 97

Conclusion 101

7 Health Policy Ian Kendall and Graham Moon 103

Ten Years of Conservative Health Policy 105

The National Health Service Review 108

Responses and Developments 113

$\begin{array}{ll}\text { Conclusion } & 115\end{array}$

8 Housing Policy in the Thatcher Years Rob Atkinson
and Paul Durden

Introduction - Housing Policy Pre-1979 117

Housing Policy Since $1979 \quad 119$

$\begin{array}{ll}\text { Local Authority Housing } & 120\end{array}$

The Privately Rented Sector $\quad 124$

Conclusions 
9 Education Policy: Education as a Business?

Malcolm McVicar

Introduction 131

The Emergent 1980s 133

The Education Reform Act 1988

Further Education $\quad 142$

Higher Education $\quad 142$

$\begin{array}{ll}\text { Conclusion } & 144\end{array}$

10 'A Caring Community'? Personal Social Services in the 1980s Neil Evans

Introduction 145

Policy Since $1979 \quad 148$

The Audit Commission Report Making a Reality of

The Griffiths Report - $1988 \quad 151$

The White Paper - Caring for People: Community Care in the Next Decade and Beyond 153

Child Abuse and the Children Act 1989

Overview and Future Trends 156

11 Away from the Dependency Culture? Social Security

Policy Francis McGlone

Short-term Remedies 161

Housing Benefit 161

Board and Lodging 162

The Green Paper - 1985

Criticisms of the Green Paper 165

The White Paper - $1985 \quad 167$

Impact of Reforms 168

$\begin{array}{ll}\text { Changes Since April } 1988 & 169\end{array}$

Assessment of Government Policy $\quad 170$

12 Local Government 1979-89: A Decade of Change

Sylvia Horton

The Conservative Government's Policies and Local

Government $\quad 172$

The Legislation $\quad 174$

Changes in Local Government Finance $\quad 176$

$\begin{array}{ll}\text { Structural Change } & 179\end{array}$

Central-local Relations $\quad 182$

The End of a Decade $\quad 184$ 
13 Equal Opportunities in a Cold Climate Carol Lupton and Dave Russell

Introduction

The Legislation

The Impact of the Legislation 189

Implementing the Legislation - Individual 190

Implementing the Legislation - Administrative Action $\quad 192$

Competing Conceptions of Equal Opportunity 193

Equal Opportunities and Thatcherism 194

The Role of the EC 195

The Role of Local Government 197

The Future of EO Policies $\quad 200$

14 'The Right to Know': Government and Information

Kelvyn Jones, Frances Millard and Liz Tirigg 203

Introduction 203

The Thatcher Years - Continuity and Change 204

Three Case Studies 211

$\begin{array}{ll}\text { Conclusion } & 217\end{array}$

15 Beyond Political Stalemate: New Thinking on Northern

Ireland Frank Lyons

The Hillsborough Accord 220

Policy Aims of the Republic of Ireland 222

Policy Aims for the Thatcher Government 223

Responses to Hillsborough 224

Policy Developments After the Agreement 226

16 Foreign and Defence Policy: The Impact of

Thatcherism Fergus Carr 231

Introduction 231

From Great Power to Regional Actor 231

The Policy Process 233

Britain and the EC 234

Britain and the Superpowers 235

Defence Policy 238

Hong Kong 240

Britain and the Commonwealth 241

Conclusions 243

$\begin{array}{lr}\text { Conclusion } & 245\end{array}$ 
Guide to Further Reading 249

Appendix 1: Legislation 1979-89 254

Appendix 2:Rate-capped Authorities 1985-6 to 1989-90 266

$\begin{array}{ll}\text { Bibliography. } & 267 \\ & 266\end{array}$

$\begin{array}{ll}\text { Inder. } & 276\end{array}$ 


\section{Acknowledgements}

The editors would like to thank all of the contributors to the book for their tolerance towards what has been a very demanding timetable of delivery. Their responsiveness to the various forms of inducement employed to meet deadlines, some of which bordered on the illegal, has made the editors' task that much more manageable. We would like to give special thanks to Rob Atkinson who, in addition to writing one and co-authoring two of the chapters, was of great assistance in advising the editors on other aspects of the book. We would also like to express our gratitude to all of those who have assisted the authors in the preparation of manuscripts. In particular, we would like to acknowledge the contribution of Carol Knight, who undertook important work on the Bibliography, and to thank Olive, Lorraine, Nicky and Heather, of the School of Social and Historical Studies, for their invaluable work on the manuscripts.

Stephen P. Savage

Lynton Robins 


\section{Notes on the Contributors}

Rob Atkinson is a Senior Lecturer in Politics in the School of Social and Historical Studies at Portsmouth Polytechnic. He has recently completed a Doctorate on housing and local government which, together with industrial policy, constitute his primary research interests. He has published a variety of articles on trade unions, urban politics and local government.

John Bradbeer is Senior Lecturer in Geography, Department of Geography, at Portsmouth Polytechnic. His interests are in environmental planning and policy, with particular emphasis on natural resources and the coastal zone, rural planning and leisure and recreation. His main publications include chapters in books on the future of mineral extraction in the British countryside; the problems of nuclear power station location in the United Kingdom; the Heritage Coasts of England and Wales; defence heritage and tourism development.

Fergus Carr is a Principal Lecturer in International Politics in the School of Social and Historical Studies at Portsmouth Polytechnic. His primary research interests are contemporary strategy and international politics in the Middle East. He is also currently pursuing Doctorate research into the American Doctrine of Limited War.

Mike Dunn is Head of the School of Economics, Portsmouth Polytechnic, and lectures in the area of industrial and resource economics. He has published widely in the field of resource economics and has published Fisheries Economics: An Introduction (with S. Cunningham and D. Whitmarsh) (Mansell/Cassell, 1985).

Paul Durden is a Senior Lecturer in Social Policy in the School of Social and Historical Studies at Portsmouth Polytechnic. His research interests focus on housing and education policy, particularly in the field of comparative social policies. He has published mainly in the area of housing policy.

Neil Evans is a Senior Lecturer in Social Work in the School of Social and Historical Studies at Portsmouth Polytechnic. Prior to this post he has worked in a variety of capacities for Social Services. His current research interests focus on provision for elderly people, and he has published articles on medical services in the community. 
David Farnham is a Principal Lecturer in Industrial Relations at the Business School, at Portsmouth Polytechnic. He has written widely on industrial relations, personnel management and employment legislation. He is author of The Corporate Environment (IPM, 1990) Personnel in Context (IPM, 1986) and co-author of Understanding Industrial Relations (with John Pimlott) (Cassell, 1990) and Public Administration in the UK (with Malcolm McVicar) (Cassell, 1982).

Sylvia Horton is Principal Lecturer in Public Sector Studies in the School of Social and Historical Studies at Portsmouth Polytechnic. Her major research interests are in local government and the civil service and she has published a variety of articles in these areas.

Kelvyn Jones is Senior Lecturer in Geography, in the Department of Geography, at Portsmouth Polytechnic. His specialist interests lie in medical geography and quantitative methods. He is author (with Graham Moon) of Health, Disease and Society: A Critical Introduction to Medical Geography (Routledge \& Kegan Paul, 1987) and holds a Doctoral thesis for work on the exploratory analysis of mortality information.

Ian Kendall is Senior Lecturer in Social Policy in the School of Social and Historical Studies at Portsmouth Polytechnic. He has recently completed editing a collection of Fabian Society papers on the NHS and co-authoring a book on complaints procedures and health services in the UK.

Carol Lupton is Senior Research Officer in the Social Services Research and Information Unit (SSRIU) within the School of Social and Historical Studies at Portsmouth Polytechnic. In addition to her research in the Unit, evaluating the quality of personal social services provided to a range of client groups, she has written and published in a range of areas including: post-war unemployment policy, feminist research practice and the development of performance indicators within local authority social service departments. She is currently editing a book on the dilemmas of feminist community work.

Frank Lyons is a Senior Lecturer in Sociology in the School of Social and Historical Studies at Portsmouth Polytechnic. His major research interests are in the area of the politics of Ireland and educational development.

Francis McGlone lectures in Social Policy in the School of Social and Historical Studies at Portsmouth Polytechnic, and also at the Polytechnic of Central London. His research interests focus on state policy, poverty and social security, and social policy with specific reference to elderly people. He has worked previously with Age Concern. 
Malcolm McVicar is Dean of the Faculty of Humanities and Social Science at Portsmouth Polytechnic. His primary research interests are in the area of education policy, particularly higher education. He has written extensively on performance monitoring in higher education, and is co-author of Public Administration in the $U K$ (with David Farnham) (Cassell, 1985).

Frances Millard is Principal Lecturer in Politics in the School of Social and Historical Studies at Portsmouth Polytechnic, where she specialises in Soviet and Eastern European Politics. Her research interests focus on social policy and issues of civil liberties. Among her major publications are Pressure Politics in Industrial Societies (with Alan Ball) (Macmillan, 1986) and editor of Social Policy and the Market (London School of Economics, 1990).

Graham Moon is Senior Lecturer in Health Studies, in the School of Social and Historical Studies at Portsmouth Polytechnic. His current interests focus on community health planning, public health and health informatics. He holds a Doctoral thesis on urban political geography and has published work in the areas on urban and local government studies, services for elderly people and health planning and policy. He is author (with Kelvyn Jones) of Health, Disease and Society: A Critical Introduction to Medical Geography (Routledge \& Kegan Paul, 1987), and is currently working (with Liz Twigg and Kelvyn Jones) on the development of consultancy work with various health authorities.

Lynton Robins is Course Leader in Public Administration at Leicester Polytechnic. He is co-author (with Bill Coxall) of Contemporary British Politics (Macmillan, 1989), editor of Talking Politics, and is currently researching aspects of post-war British politics.

Dave Russell is Senior Lecturer in Sociology, School of Social and Historical Studies at Portsmouth Polytechnic. His major research interests are in the areas of race and anti-racism, states and society and professions and public policy. He has published various articles in journals and books on South Africa, and on British racism.

Stephen P. Savage is Senior Lecturer in Criminology and Police Studies at Portsmouth Polytechnic. His Doctoral work was in the area of social theory, and his current research interest focuses on criminal justice and policing policy. He has written variously in the area of sociological theory, social policy and criminology, and he is author of The Theories of Talcott Parsons (Macmillan, 1981) and coauthor of Education and Social Policy (Macmillan, forthcoming).

Sandy Smith is a Senior Lecturer in the School of Economics at Portsmouth Polytechnic, and has a particular interest in the economics of central planning and market socialism. He has 
published a number of papers in the area of economic theory, and particularly on the Soviet economy.

Liz Twigg lectures in Social Statistics in the School of Social and Historical Studies and the Department of Geography at Portsmouth Polytechnic, and also holds a Research Fellowship in health and health care information. She is currently working on a public health database for Winchester Health Authority and completing her Doctoral thesis on geographical aspects of health information. She has published on geographical information systems, official health statistics and statistical methods. 


\section{Glossary of Acronyms and Political Terms}

ACAS Advisory Conciliation and Arbitration Service ANC African National Congress

ASI

Adam Smith Institute

BA British Airways

BAA British Airports Authority

BES Business Expansion Scheme

BT British Telecom

BTG British Technology Group

BUPA British United Provident Association

CAP Common Agricultural Policy (EC)

CBI Confederation of British Industry

CC Community Charge

CEC Commission of the European Communities

CFCs Chlorofuorocarbons

CHB Child Benefit: a non-means-tested allowance payable to the main carer of a child, usually the mother

CHOGM Commonwealth Heads of Government Meeting

$\mathrm{CO} \quad$ Certification Officer/Office

COI Central Office of Information

CPAG Child Poverty Action Group

CPS Centre for Policy Studies

CRE Commission for Racial Equality

CRTUM Commissioner for the Rights of Trade Union Members

CSO Central Statistical Office

CTC City Technology College

DE Department of Employment

DES Department of Education and Science

DHA District Health Authority

DHSS Department of Health and Social Security

DOE Department of the Environment

DOH Department of Health

DOI Department of Industry

DPR Data Protection Registrar 
DSS Formerly DHSS, responsible for the administration of social security

DTI Department of Trade and Industry

EC European Community

EEC European Economic Community, now known as EC

e-i-a environmental-impact-assessment

EMS European Monetary System

EO

Equal Opportunity

EOC Equal Opportunities Commission

EPG Eminent Person's Group

ERM

ESA

ET

Exchange Rate Mechanism (of the EMS)

EZ

Environmentally Sensitive Area

Employment Training

Enterprise Zone

FC

Family Credit: a means-tested benefit payable to families on low wages, replacing FIS (see below) from April 1988

FO Foreign and Commonwealth Office

FIS Family Income Supplement

FMI

FPA

Financial Management Initiative

FPC

Family Practitioner Authority

Family Practitioner Committee

GCHQ General Communications Headquarters

GLC

Greater London Council

GNP

Gross National Product

Go7

Group of 7 (economic powers)

GSS

Government Statistical Service

HAT Housing Action Trust

HB

Housing Benefit: a means-tested housing subsidy for people in rented accommodation and owner-occupiers (general rates only) administered by the local authority

IBA Independent Broadcasting Authority

IEA Institute for Economic Affairs

IHSM Institute of Health Service Management

ILEA Inner London Education Authority

IMF International Monetary Fund

INF Intermediate-Range Nuclear Forces

INLA Irish National Liberation Army 
IS

IT

ITC

LEA

LFA

\begin{tabular}{|c|c|}
\hline MAFF & Ministry of Agriculture, Food and Fisheries \\
\hline MCC & Metropolitan County Council \\
\hline MINNIS & Management Information Systems for Ministers \\
\hline MOD & Ministry of Defence \\
\hline MSC & Manpower Services Commission \\
\hline MTFS & Medium Term Financial Strategy \\
\hline NATO & North Atlantic Treaty Organisation \\
\hline NCC & National Curriculum Council \\
\hline NCCL & National Council for Civil Liberties \\
\hline NEB & National Enterprise Board \\
\hline NHS & National Health Service \\
\hline NIB & $\begin{array}{l}\text { National Insurance Benefit: benefit based on a record of } \\
\text { contributions into the National Insurance scheme }\end{array}$ \\
\hline NIMBY & 'Not in my back yard' \\
\hline NNDR & national non-domestic rate \\
\hline NSPCC & $\begin{array}{l}\text { National Society for the Prevention of Cruelty to } \\
\text { Children }\end{array}$ \\
\hline
\end{tabular}

OFGAS regulatory agency for British Gas

OFTEL regulatory agency for British Telecom

QGA Quasi-governmental Agency

QUANGO Quasi-autonomous Non-governmental Organisation

QUELGO Quasi-elected Local Government Organisation

RHA Regional Health Authority

RPI Retail Price Index 
xviii Glossary

RSG Rate Support Grant

RUC Royal Ulster Constabulary

RWA Regional Water Authority

SB Supplementary Benefit (see IS above)

SDI Strategic Defense Initiative (US)

SDLP Social Democratic and Labour Party (N. Ireland)

SEA Single European Act

SEAC Schools Examination and Assessment Council

SERPS State Earnings Related Pension Scheme: a National Insurance contributory additional state pension for employees only

SF Social Fund: a cash-limited discretionary fund of loans and grants for exceptional needs, replacing single payments from April 1988

SNF Short-Range Nuclear Forces

SPZ Simplified Planning Zone

SSD Social Services Department

SSSI Site of Special Scientific Interest

TC Training Commission (formerly MSC)

TEC Training and Enterprise Council

TUC Trades Union Council

TVEI Technical and Vocational Education Initiative

UDC Urban Development Corporation

UDI Unilateral Declaration of Independence (Rhodesia)

UDR Ulster Defence Regiment

UFC University Funding Council

UNESCO United Nations Economic and Social Council

WCC Welsh Curriculum Council

YOP Youth Opportunities Programme

YTS Youth Training Scheme 